\title{
A importância das atividades carnavalescas na vida dos idosos
}

\author{
Matilde Maria de Magalhães Arena Corrêa* \\ ORCID iD 0000-0003-3444-3531 \\ Universidade Estadual de Campinas, Instituto de Ciências Médicas, Campinas, Brasil
}

\author{
Olga Rodrigues de Moraes von Simson* \\ ORCID iD 0000-0002-7010-9920 \\ Universidade Estadual de Campinas, Instituto de Ciências Médicas, Campinas, Brasil
}

Resumo: $\mathrm{O}$ presente artigo se refere aos idosos participantes de escolas de samba do interior paulista: uma de Campinas, a Rosa de Prata, e a outra de Duartina, Unidos da Vila. Nesta pesquisa, foram realizadas entrevistas que tinham como objetivo demonstrar através de trechos das narrativas dos colaboradores suas atividades carnavalescas e o quanto isso pode ter contribuído com o envelhecimento bemsucedido, teoria no campo da Gerontologia, que considera vários aspectos como: a subjetividade dos idosos, sua autopercepção, características culturais e, principalmente, que o bem-estar na velhice não é responsabilidade apenas individual, mas coletiva. A pesquisa se utilizou da História Oral no campo das artes, com entrevistas que foram gravadas e transcritas, e também do recurso de imagens fotográficas.

Palavras-chave: Envelhecimento. História Oral. Escola de samba. Idosos.

\section{The importance of carnival activities in the life of the elderly}

Abstract: This article refers to the elderly participating in samba schools in the interior of São Paulo: one from Campinas, Rosa de Prata, and the other from Duartina, Unidos da Vila. For the research, interviews were conducted that aimed to demonstrate through excerpts from the narratives of collaborators involved

Doutoranda em Gerontologia pela Universidade Estadual de Campinas (Unicamp), com orientação da Profa Dra. Olga Rodrigues de Moraes von Simson. E-mail: mmatildinha@gmail.com.

" Doutora em Ciência Social (Antropologia Social) pela Universidade de São Paulo (USP), 1990, e pósdoutora pela Universidade de Tübigen - Geographisches Institut, 1993. E-mail: osimson@uol.com.br. 
in carnival activities and how much this may have contributed to successful aging, a theory in the field of Gerontology, which considers several aspects such as: the subjectivity of elderly people, their selfperception, cultural characteristics and, above all, that well-being in old age is not only an individual responsibility, but a collective one. The research used Oral History in the field of arts, with interviews that were recorded and transcribed, and also the resource of photographic images.

Keywords: Aging. Oral History. Samba school. Elderly.

As histórias de vida estão povoadas de coisas perdidas que se daria tudo para encontrar: elas sustentam nossa identidade, perdê-las éperder um pedaço da alma.

(Bosi, 2019, p. 31)

O presente artigo é baseado na pesquisa, ainda em processo de finalização, que tem o título provisório $A$ participação dos idosos nos desfiles carnavalescos e o pertencimento à comunidade do samba: aspectos educativos e os beneficios para o seu bem-estar.

A pesquisa objetivou entrevistar as mulheres idosas da escola de samba Rosa de Prata, de Campinas (SP), a qual já era pesquisada desde o mestrado, porém com outro foco. Na pesquisa de mestrado, com o título Escola de samba e Projetos de Trabalho com crianças: relaçôes entre arte, educação e cultura, foram consideradas as falas do presidente da escola de samba e do carnavalesco de que os idosos representavam a manutençáo das tradiçôes da comunidade e do carnaval, por isso, no doutorado, o objetivo foi dialogar com as mulheres idosas da escola de samba, no sentido de re-conhecê-las e valorizá-las nessa manifestação cultural e artística.

No entanto, o bairro da escola de samba Rosa de Prata, Vila Castelo Branco (antiga Vila Bela), de Campinas, é um bairro de idosos. Nessa comunidade, a maioria das idosas da Ala das Baianas havia morrido ou náo se encontrava em condiçóes mentais para participar das entrevistas, por isso, ampliamos a pesquisa para os homens idosos da escola e duas senhoras da Ala das Baianas de uma escola de samba de Duartina (SP).

A pesquisa foi qualitativa e participativa. A pesquisadora, após ir a campo assistir a alguns ensaios da bateria da Rosa de Prata em 2018 e 2019, conhecia pessoas da escola e contactava por celular as filhas das idosas ou os próprios idosos e lhes explicava a pesquisa e seus objetivos, em seguida era marcado um encontro nas casas dos idosos com dia e horário da preferência deles. Um roteiro prévio foi pensado com questóes sobre suas participações nas escolas de samba, assim como as condiçôes educacionais, do bairro e de saúde dos idosos. Os assuntos foram analisados seguindo esses eixos temáticos.

De acordo com Borges e Borges (2021), a metodologia da História Oral vem traçando um longo percurso, desenvolvendo-se, principalmente, após a II Guerra Mundial, com a democratização da história da humanidade e a revolução tecnológica que auxiliaram, de certa maneira, a História Social. Estudos realizados em Chicago e na Inglaterra nos anos de 1950 e 1960, e no Brasil mais nos dias atuais, contribuíram 
com a consolidaçáo dessa metodologia, entrelaçando vários campos de estudo como a História, a Sociologia e a Antropologia, que mobilizaram diferentes parâmetros qualitativos de investigação que se apoiam na oralidade.

As entrevistas orais que fazem parte da História Oral são analisadas atualmente sob diferentes e modernas perspectivas que constituem novas informaçóes e caracterizam novos fenômenos da experiência humana. Os materiais das entrevistas representam percepçóes sociais, sendo sujeitas às pressóes sociais de seus grupos de origem, que podem ter sido silenciadas por tendências historiográficas tradicionais que deixam determinados sujeitos de lado. A História Oral traz a história de determinados grupos para dentro da comunidade (Borges; Borges, 2021).

Segundo Lima (2020), há diferentes tipos de História Oral, sendo as entrevistas o coração dessa metodologia. Os tipos são: a História Oral de histórias de vida, que mergulha profundamente nas histórias dos sujeitos, muitas vezes, desde o seu nascimento, e a de histórias de vida temáticas, que permite selecionar temas ou tópicos que o pesquisador tem interesse em aprofundar em sua pesquisa. A presente pesquisa se utilizou da história de vida temática.

A História Oral, no campo das artes, tem suas especificidades, como no caso desta pesquisa, podendo lidar com os imprevistos, como a possibilidade de surgirem outras formas de obtenção das narrativas, muitas vezes, criativas, não passivas, em movimento e que consideram os entrevistados em seu universo artístico (Santhiago, 2016).

As histórias dos idosos das escolas de samba foram deflagradas através de o que Cándida Smith (2012) chamou de "cadeia de performances", ou seja, por meio de cantos, de leituras de trechos de livros de poesia, de quadros de pintura, de demonstraçáo dos passos das baianas e por meio de sambas tocados em instrumentos de percussão, formas que, além das entrevistas, contribuíram para compor o "circuito de subjetividade", ${ }^{1}$ que possibilitaram uma visão mais complexa do tema pesquisado.

Várias pesquisas no campo das artes, com o uso da História Oral, demonstraram trajetórias de pessoas tendo em comum as artes, com várias narrativas envolvendo imaginação, criações, mesmo em pessoas não artistas profissionais (Santhiago, 2016). Era o caso de alguns idosos da pesquisa nas escolas de samba, que tinham em comum memórias perpassadas por uma paixão, pelo espírito de comunidade envolvendo geraçóes, em prol do objetivo que era a participação na comunidade carnavalesca. Eles não tinham apenas o objetivo de verem sua escola campeã ou competir no carnaval, mas viverem momentos prazerosos, coletivos, de expressão corporal, de emoçóes, mesmo na velhice, quando são transmitidas ideologias de que nessa fase não é possível tais expressóes.

1 Formas expressivas de subjetividade, como gestos, danças, expressões corporais, olhares que configuram outras formas de "dizer" as palavras e que vão compondo um circuito de informações e significados sobre as histórias dos colaboradores (Cándida Smith, 2012). 
Como mencionado, a pesquisa contou com a participação dos idosos das escolas de samba Rosa de Prata, de Campinas e a Unidos da Vila, de Duartina. Tivemos a participação de cinco mulheres e dois homens no presente projeto, com idades entre 69 e 86 anos.

Os artistas ou pessoas envolvidas no carnaval, assim como os idosos, não apenas trazem questóes subversivas, contestadoras ou uma arte romântica, com poemas no samba enredo, mas também, ao participarem das escolas de samba, buscam um envolvimento com a alegria, com o coletivo e com as geraçóes mais novas. Alegrarse, dançar, cantar, se embelezar, foliar, são palavras e sentimentos que se fizeram presentes nos relatos dos colaboradores das escolas de samba, porém difíceis de serem incorporados na sociedade capitalista, principalmente em relaçáo às pessoas que estáo envelhecendo.

Portanto, a História Oral pode problematizar formas constituídas, cárceres identitários, presas em domínios autorizados, como os estereótipos sobre o envelhecimento, através de relatos de experiências cotidianas dos próprios velhos, que muitas vezes, não estão escritos em livros e que podem demonstrar visóes contrárias dessas formas constituídas sobre a velhice (Perelmutter, 2016).

A vida no campo das artes já era expressiva no Brasil, no fim dos anos 1950, mas limitada a círculos restritos, com objetivos mercadológicos. Poucos estudos falam dos artistas das periferias, como Dona Isabel Mendes, ceramista do Vale do Jequitinhonha (MG), citada por Worcman (2016) em seu artigo.

Os idosos e, ainda mais, as mulheres idosas no universo do samba são pouco valorizadas. Dona Ivone Lara, enfermeira, terapeuta ocupacional na área da saúde mental no Brasil, tornou-se sambista com quase cinquenta anos, sendo exemplo, assim como Dona Irene, nossa entrevistada, de compositoras de samba que tiveram que enfrentar a resistência e predominância masculina nesse universo em uma época na qual eram educadas para serem esposas e donas de casa (Nobile, 2015).

A tese sobre os idosos nas escolas de samba se utilizou também do recurso das fotografias. A pesquisadora tirou fotos do seu celular dos momentos das entrevistas, dos objetos dos sujeitos sobre o samba e das fotos antigas reveladas sobre a participaçáo do idoso na escola - o que náo foi muito fácil conseguir por elas terem sido perdidas ou deterioradas.

Simson [s. d] nos fala que os registros fotográficos permitem aos pesquisadores estabelecerem relaçôes mais consistentes com os participantes das pesquisas, fornecendolhes melhor compreensão do assunto, ampliação do roteiro das entrevistas e, portanto, mais conhecimentos. Além das fotos também proporcionarem fácil divulgação e compreensão dos resultados para um público vasto.

Meihy (2012), fala que a metodologia da História Oral utilizada em projetos de pesquisa, ao ressignificar memórias individuais e inseri-las num contexto coletivo de uma determinada comunidade, tem o papel de preservar e valorizar determinados 
grupos, como o dos velhos, o que possibilita também que eles se integrem socialmente e construam identificaçôes projetivas com outros idosos (Rovai, 2017).

Portanto, a História Oral também deve ter um compromisso com a devoluçáo das análises das narrativas aos seus colaboradores, enriquecendo suas visóes sobre si mesmos, sobre seu grupo, representando-os e, levando-os a refletirem sobre uma possível invenção e reinvenção da realidade (Perelmutter, 2016).

O envelhecimento vem aumentando em nosso país. A busca pelo significado do que seria envelhecimento bem-sucedido iniciou-se em 1944, nos Estados Unidos. O termo foi mencionado no campo da Gerontologia, em 1961, por Robert Havighurst. ${ }^{2}$ $\mathrm{O}$ conceito de envelhecimento bem-sucedido considera as abordagens integrativas (sociais, psicológicas, físicas, entre outras), a subjetividade, a autoavaliação dos idosos e as diferenças socioculturais. Laços sociais eram considerados significativos para o bem-estar dos idosos e evidenciavam, em alguns estudos, um aumento da capacidade funcional deles quando envolvidos em atividades comunitárias e quando traçavam metas para suas vidas (Teixeira; Neri, 2008).

Para Lima, Silva e Galhardoni (2008), a velhice bem-sucedida não é ausência de doenças ou limitações físicas, mas sim uma percepção e avaliação subjetiva por parte dos idosos, que traz consideráveis níveis de satisfação e memórias positivas em relação as suas vidas.

Apesar da teoria do envelhecimento bem-sucedido não focar apenas nas doenças dos idosos e sim em diversos aspectos, como os emocionais, sociais e antropológicos, seus esforços não se comparam aos das perspectivas sociológicas em relação ao envelhecimento, ainda mais nos dias atuais, com a pandemia da Covid-19, em que as questôes morais, econômicas e biológicas passam por cima da justiça social e das questóes sociais (Lucena, 2021).

Atualmente notamos, principalmente em relação ao tema da velhice, a presença de políticas de piedade e controle, frutos da biopolítica que exerce poder sobre o homem enquanto ser vivo, visando sua longevidade, por exemplo, através de mediçóes estatísticas, de diferentes maneiras de intervenção, controlando seus corpos de forma massificante e disciplinarizante com tecnologias que têm o objetivo de diminuírem a morbidade e prolongar a vida, mas sem qualidade. Os idosos são vistos como doentes na fase final da vida, próximos da morte, por isso, as políticas públicas passam para as famílias e instituiçóes privadas a responsabilidade para com eles, ou então, passam a visão de que devem ser apenas assistidos em suas doenças, considerando-os sem autonomia, sem acesso e direitos a uma vida plena, e os mais velhos com menos condiçóes sociais

2 Robert James Havighurst foi um químico, físico, educador e especialista em desenvolvimento humano e envelhecimento. Havighurst trabalhou e publicou até seus 80 anos. Ele morreu de doença de Alzheimer em janeiro de 1991 em Richmond, Indiana, aos 90 anos de idade. Disponível em: https://en.wikipedia. org/wiki/Robert_J._Havighurst. Acesso em: 25 maio 2021. 
são mais prejudicados ainda (Lucena, 2021).

Com a pandemia da Covid-19, os idosos foram classificados como "grupo de risco" e isolados. A falta de leitos e respiradores faz com que escolham quem deve viver e quem deve morrer, produzindo, assim, uma política da morte, uma necropolítica, que escolhe entre os mais jovens, por considerá-los produtivos e enriquecedores da economia. Idosos não são pessoas à espera da morte que devem ficar num canto, daí a importância de perspectivas e políticas que relacionem os serviços de saúde aos sociais, centrando na pessoa idosa, com suas especificidades, diferenças e direitos que não devem ser massificados pela biopolítica, por isso, sublinhamos a importância deles serem considerados nas artes, nas comunidades do samba, na coletividade e em suas histórias.

\section{Os idosos nas escolas de samba}

A seguir, apresentaremos trechos das narrativas, que foram gravados e autorizados através do Termo de Consentimento Livre e Esclarecido (TCLE) pelos colaboradores e aprovados também pelo Comitê de Ética em Pesquisa (CEP). As narrativas foram transcritas na tese e selecionamos para este trabalho alguns trechos delas que demonstram os momentos de participação dos idosos nas escolas de samba.

A primeira idosa entrevistada foi Dona Irene da Silva, de 86 anos, que iniciou sua participação no universo do samba na Escola Estrela D'alva (no bairro Vila Costa e Silva, em Campinas) ainda moça. Ia com os irmãos aos bailes no saláo da escola.

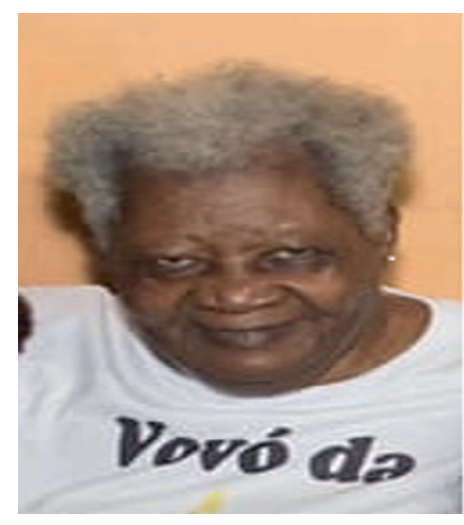

Imagem 1- Dona Irene da Silva, 86 anos, durante a entrevista.

Fonte: arquivo das autoras. 
Mulheres naquela época, entre 1960 e 1970, não saíam sozinhas no carnaval, principalmente aos desfiles de rua. Dona Irene quando se casou ficou por vinte e um anos sem participar do carnaval, devido ao marido que náo a permitia dele participar. Após a morte do esposo e morando na Vila Castelo Branco (Vila Bela), começou a participar da escola de samba do bairro, a Rosa de Prata. Foi diretora da escola em questão, compositora e "tiradora" (termo muito usado pelos participantes de escolas de samba, que significa: coordenar, conseguir e organizar pessoas que participam de uma determinada ala dentro do enredo ou do desfile, além disso, "tirar" ala também significava ter um coordenador que ensaiava os membros dela, e que podia desenhar, bordar ou costurar a fantasia dessa ala). Dona Irene fala que levou as filhas, filhos e netos para o desfile e suas funçóes eram:

Coordenar [a ala], fazer a roupa, pegar os integrantes. Eu gostava de trabalhar, costurar, a gente trabalhava com muita coisa, fazia fantasia de batuqueiro, bordava os maiôs das passistas tudo com lantejoula, a gente bordava tudo aqui em casa, peça por peça, então a gente fazia muita coisa, muita coisa mesmo. (Irene da Silva, 2019).

Durante a entrevista, Dona Irene comentava (na presença da filha Noélia, que também participou como porta bandeira da escola e como "tiradora" de alas) com entusiasmo, as suas experiências na escola de samba:

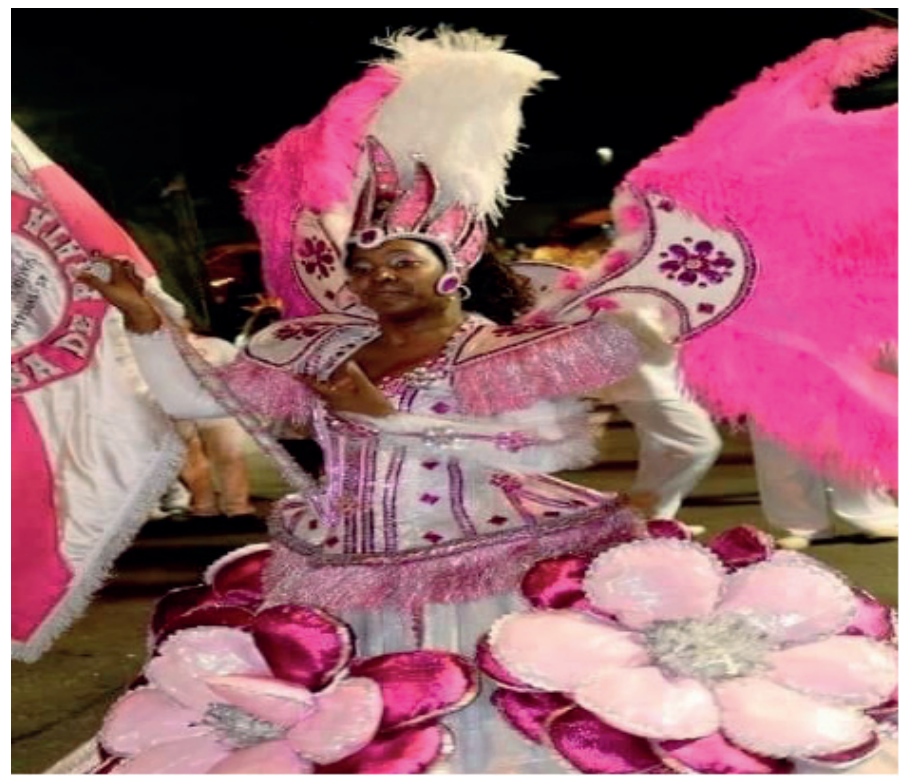

Imagem 2 - Noélia (filha de Dona Irene), que acompanhou a mãe na entrevista e era porta-bandeira da Rosa de Prata. Fonte: arquivo das autoras. 
Eu sou apaixonada pela Rosa de Prata, minha escola preferida. A escola tem trinta e poucos anos, eu não peguei da fundação não, porque quando fundou meu marido ainda era vivo, depois que eu comecei a frequentar, eu comecei assim indo no desfile e levando as meninas para ver o desfile, a gente chegava do serviço, todo mundo subia pra ver e a gente subia junto, foi daí que a gente começou e aí eu fui convidada para tirar uma ala de criança (hoje a criançada tá tudo casada com filho e neto). Eles "vinham" aqui em casa para fazer a fantasia. Minha casa sempre foi assim [mostra com a mão fazendo um gesto amplo de cheia]. Depois quando meus filhos já grandes saíam tinha a ala das meninas e a ala do meu filho com os amigos dele. Na época de Carnaval era uma "trançassáo" de cabelo aqui em casa, tudo o que você pensasse da escola era feito aqui em casa, era muito movimentado mesmo. Aí nessa época de colar penas a gente não tinha como secar porque a escola ia sair no outro dia. As penas estavam todas cruas antes de colocar no palito, aí a Dona Isso... a Dona Aquilo, a Dona Ana, colocava tudo no forno. Toda vizinhança ajudava. Às vezes, eram duas, três horas da madrugada a gente ainda tava fazendo carro alegórico. (Irene da Silva, 2019).

Dona Irene participava muito da Rosa de Prata como vimos através de seus relatos. Além disso, tinha conhecimento do funcionamento da Ala das Baianas, pois participava do desfile em outras cidades quando a escola vencia. Sua participação lhe possibilitava ter contato com políticos, vereadores e radialistas da cidade. Foi filiada ao Partido do Movimento Democrático Brasileiro (PMDB), participou do movimento das Diretas Já, do movimento Comunidade e Democracia e do Movimento Negro na regiáo. Ela também realizava excursóes com pessoas do bairro. Portanto, a participaçáa no mundo do samba a possibilitava uma convivência social muito intensa, assim como exercer sua cidadania participando tanto da política como de movimentos sociais.

Essa senhora, que fez até o $4^{\circ}$ ano do atual ensino fundamental (antigo curso primário), disse que aprendeu tudo observando as grandes escolas de samba do Rio de Janeiro e de São Paulo e através de revistas como Cruzeiro e Manchete (riquíssimas em imagens carnavalescas), muito presentes nas décadas de 1970 e 1980.

[...] foi só de observar, nunca tive... pra você ter uma ideia eu nunca dancei no Carnaval na rua, eu acompanhei como diretora, mas nunca peguei uma fantasia. Como diretora ia com um terno, eu ia pra avenida, quando acabava, quando 'nós ganhava', a gente descia abraçados fazia um cordáo da diretoria na Francisco Glicério, levando a escola. Sempre que a Rosa passava por último a turma acompanhava, entrava um pouco antes e vinha o povo atrás cantando a música da escola. Era muito bom... Depois que o Seu Rubens morreu eu parei, não fui mais, aí entrou esses meninos aí... [referindo-se às novas diretorias] mas, mesmo assim eu ajudei o Seu Rubens aqui, eu continuei trabalhando, só não fui mais. Tudo na raça, era de olhar, observar, amor. (Irene da Silva, 2019). 
A segunda idosa presente nas entrevistas para a tese foi Dona Isabel Augusto. Não nos concedeu entrevista, pois estava com possível diagnóstico de depressão. Entáo, sua filha Eliana, que também era muito ativa na escola, nos contou sobre a participação da mãe e nos forneceu muitas fotos que o pai tirava por ocasião da participação da mãe no samba.
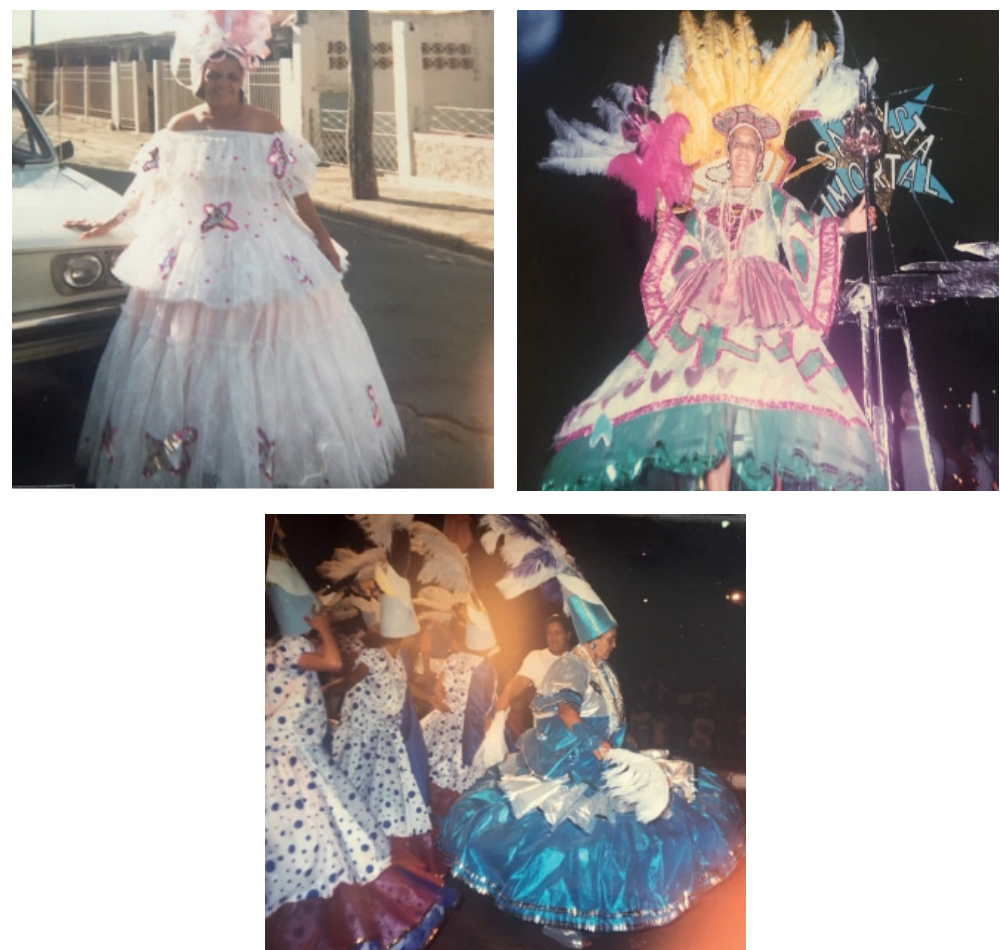

Imagens 3 a 5 - Dona Isabel Augusto, 79 anos, coordenadora da Ala das Baianas da Rosa de Prata. Fonte: arquivo das autoras.

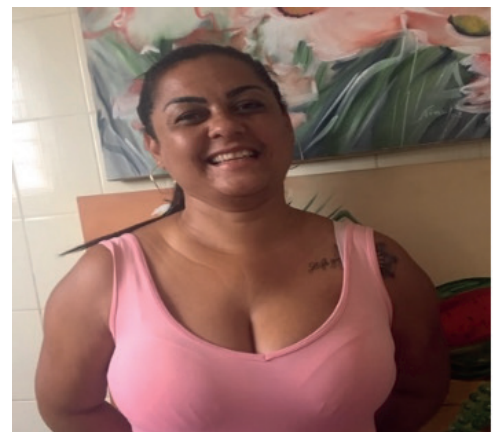

Imagem 6 - Eliana Augusto, 45 anos, filha de Dona Isabel, durante a entrevista. Fonte: arquivo das autoras. 
Consideramos Eliana como porta-voz das memórias da mãe, Dona Isabel, que foi coordenadora da Ala das Baianas da Rosa de Prata. Mesmo narrando de seu próprio espaço, com sua subjetividade e olhar externo, Eliana também pertenceu à comunidade da escola de samba, acompanhando de perto as experiências que a mãe vivenciou. Além disso, Eliana e sua mãe possuíam um acervo fotográfico de momentos da escola muito rico e que quase ninguém da Rosa de Prata tinha e este foi fornecido à pesquisadora. Mesmo a mãe impossibilitada de narrar sua história, consideramos que a colaboração de sua filha com depoimentos seria importante para o náo esquecimento da participaçáo da senhora na escola de samba (Dezemone, 2018).

Para Boltanski (1982) apud Dezemone (2018), alguns sujeitos que se relacionaram com o grupo estudado poderiam ser reconhecidos ou autorizados a falar em nome de outros, sendo porta-vozes das histórias desses sujeitos, como no caso de Eliana, ao contar sobre a participação de sua mãe na Rosa de Prata.

Dona Isabel começou a desfilar por incentivo da filha ainda jovem. O presidente da escola na época pediu para Dona Isabel criar a Ala das Baianinhas. Ela concordou, gostou e se comprometeu com a ala mirim. Segundo sua filha Eliana, tudo começou assim:

Ela me viu participando, começou a ir aos ensaios, daí o ensaio passou para a quadra que era em frente à casa dela, entáo, o presidente da escola chamou ela para ser destaque das baianas. Ela que desenhava os vestidos dela e os bordava, fazia todas as coisas. Minha mãe, acho que entrou uns três anos depois de mim, acho que em 1988, e ela sempre foi da Ala das Baianas. Ela tinha uns vestidos em casa guardados até certo tempo, depois ela ficou táo assim [deprimida]... Ela era o destaque das baianas, a roupa dela era diferente, ela era a baiana que vinha puxando as outras. Daí, ela falou que queria ser destaque pro presidente da escola, mas que queria colocar uma ala de baianinhas, e ele deixou e ela colocou (hoje já estáo todas moças). Elas [baianinhas] ficavam todas sentadinhas esperando. Ela fazia as baianinhas sentarem. Elas só obedeciam minha mãe. Elas ficavam juntas na avenida, ela tomava conta de todas, todas iam com crachazinhos, às vezes, iam desfilar táo tarde, tadinhas, umas queriam dormir... junto ficavam as senhoras. Foi uma iniciativa linda da minha mãe. Pena que tudo o que é bom dura pouco. (Eliana Augusto, 2019).

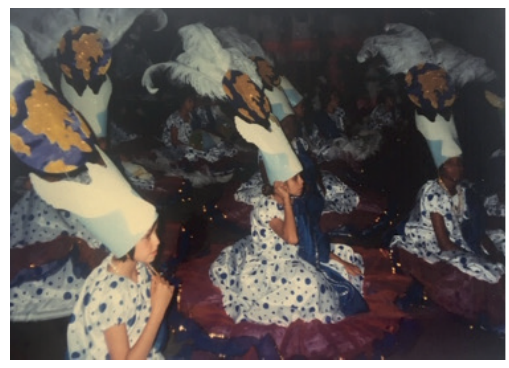

Imagem 7 - Ala das Baianinhas, criada por Dona Isabel.

Fonte: arquivo das autoras. 
Mas, segundo Eliana, sua mãe ficava eufórica antes e durante os desfiles.

Ai, minha mãe ficava eufórica, ela gostava. O Rubão, que foi presidente da escola, colocava os desenhos na parede lá na sede e a gente sempre ficava indo no ensaio. Ela ia na casa dele, ela conversava, ela brigava, ficava brava, porque queria o pano assim, assim, o resto o meu pai que comprava. E o Rubão sempre fazia a vontade dela e de todo mundo, lá de casa. Ela escolhia os colares, ela gostava, ficava bem eufórica. Ela ia ensaiar, meu pai sempre passava lá para ver como estava, todo mundo participava, eu comecei a colocar minha sobrinha, então todo mundo se envolveu. (Eliana Augusto, 2019).

O terceiro entrevistado da pesquisa foi Seu Aluízio Jeremias. Ele foi um dos fundadores da escola de samba Rosa de Prata. Foi presidente da escola, assinava documentos, cuidava da parte burocrática, autorizava enredos e os criava, às vezes. Como era artista plástico autodidata, cantor e tocador de samba, fazia tudo isso também na escola de samba. Seu Aluízio nasceu na comunidade Porteira Preta, em Campinas, onde fica o atual bairro Cambuí. Desde pequeno ouvia e assistia da janela os batuques de samba, e depois nas rádios dos vizinhos, que escutava atrás do armário ou encostando a orelha na parede. Já adulto, conheceu primeiramente a escola de samba Estrela D'alva, que era de seu parente, conhecido como Beiçola. Teve um problema nessa escola envolvendo uma mulher, então saiu de lá e teve a ideia de montar uma escola no bairro da Vila Bela. Conseguiu concretizar seu objetivo com o parceiro Paulo Vieira, em 1976. Recrutou pessoas, comprou instrumentos e com pouca verba fizeram um bom carnaval naquele ano e a escola foi ganhando nome e vitórias com alguns desfiles. Seu Aluízio também realizou seu grande sonho que foi a criação da Rosa do Futuro, uma escola composta só de crianças. Ele nos contou como foi esse processo:

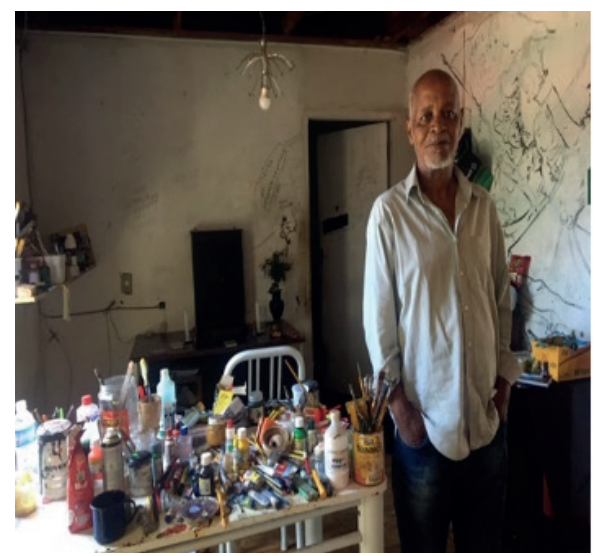

Imagem 8 - Seu Aluízio Jeremias, 80 anos, durante a entrevista.

Fonte: arquivo das autoras. 
[...] eu fundei a Rosa do Futuro, era escola de criança, essa é a escola do meu coração. A Rosa de Prata eu falo, mas eu não tenho recordação, você lidar com adulto, principalmente gente sem instrução, é muita ingratidão, muita traição, muita falsidade. Agora as crianças... eu vou dizer uma coisa... eu fiz a escola de crianças porque quando eu era pequeno, eu gostava de tocar frigideira, os caras tiravam de mim e ainda davam um "croque" em mim... E aí um dia eu pensei, eu vou fundar uma escola de samba pras crianças de 0 a 18 anos, aí na minha escola não vai ter isso, uma vez até teve, o cara tomou de um menino e eu falei: pára, deixa ele tocar, é porque eu passei por isso, ele não vai passar. (Aluízio Jeremias, 2019).

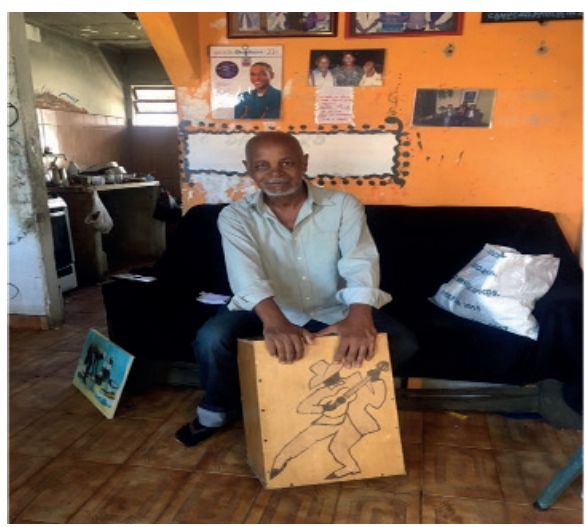

Imagem 9 - Em alguns momentos da entrevista, Seu Aluízio relembrava sambas tocando cajón (instrumento de percussão em formato de caixa).

Fonte: arquivo das autoras.

Dona Mercedes foi a quarta entrevistada. Essa senhora começou a desfilar na Rosa de Prata já adulta, também depois que o marido morreu. Saiu na Ala das Baianas e participou da diretoria. Ela conta como foi sua participação:

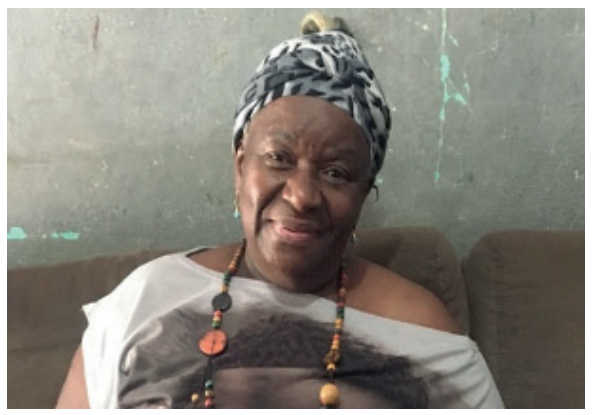

Imagem 10 - Dona Mercedes dos Santos, 69 anos.

Fonte: arquivo das autoras. 
A única escola que eu me interessei em sair na Ala das Baianas foi na Rosa de Prata. Em todas as outras escolas eu saía de diretora, acompanhando as alas. Existia antigamente muitas alas bonitas e você ia junto para cuidar de seus filhos, cada um ia junto pra cuidar da ala das crianças, sempre foi assim. Eu só fui mesmo me interessar pela ala de baiana quando eu divorciei e quando as crianças estavam tudo grande. Meu filho é batuqueiro da Rosa de Prata, ele ama a Rosa de Prata e náo tem jeito, a gente fica com isso na pele esperando o Carnaval. Meu filho Fernando toca na bateria da Rosa de Prata, toca o surdáo. A paixão da vida dele é a Rosa de Prata. Qualquer festa que eles fazem aqui, lota, sai gente pelo ladráo, eu vou em toda festa. Mas, assim começou a minha trajetória, depois que me separei fiquei livre, aí eu não tinha mais marido para me prender. (Mercedes Santos, 2019).

Dona Mercedes continua narrando sua participação na Rosa de Prata, na Ala das Baianas, ala pela qual teve resistência em sair no início, mas depois a paixão ficou grande e nela permaneceu por muitos anos:

Eu me interessei em desfilar na Ala das Baianas da Rosa de Prata quando eles homenagearam o Sindicato das Domésticas. E nesse ano eu não quis sair nessa ala das domésticas que minhas colegas foram, tinha avental, tinha tudo e eu não quis. Aí nesse ano, o Seu Aluizio homenageou as empregadas domésticas. Aí desse dia em diante eu nunca mais saí na diretoria, e eu falei eu vou sair de baiana! E ninguém acreditou aqui em casa. No ano seguinte, eu falei eu vou sair de baiana. A homenagem que fizeram às domésticas fez eu perder a vergonha, foi lá no Tancredão e eu lá. $\mathrm{Na}$ arquibancada todo mundo me chamava. Eu tinha vergonha de desfilar na Ala das Baianas ou desfilar em qualquer ala. Eu sempre desci fazia uma roupa de diretora, se era branca era branca inteira, uniforme de diretoria, neste ano eu desfilei na diretoria e usei um macacão. Neste dia eu desci com um macacáo tinha uns buracos mostrando tudo as cochas, lá na arquibancada todo mundo ria e chamava: louca! Sou louca e daqui pra frente eu vou continuar sendo louca, nunca mais eu parei. Aí eu falei para os meus filhos: ninguém se meta na minha vida que o ano que vem eu vou sair de baiana, ninguém acreditou aqui de casa, na hora em que eu apareci na avenida. Acho que fiquei uns oito anos saindo de baiana. (Mercedes Santos, 2019). 


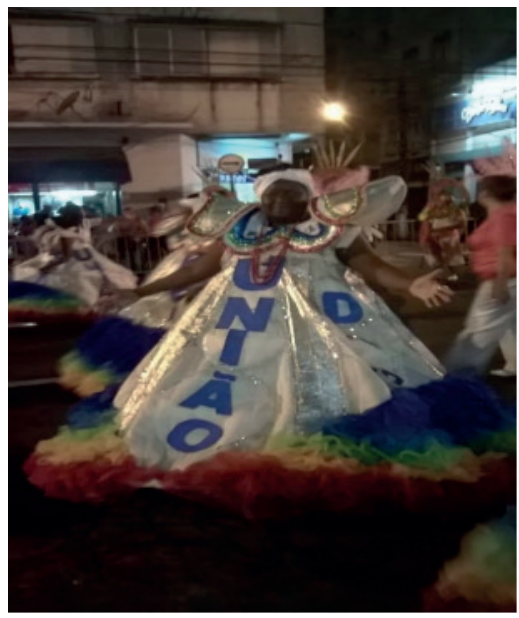

Imagem 11- Dona Mercedes desfilando como baiana na Avenida Francisco Glicério, em Campinas. Fonte: arquivo das autoras.

A quinta entrevista foi realizada com Dona Silvia, de 70 anos de idade. Ela nos relatou que sempre gostou de carnaval, porém, foi em 2015 que foi convidada a sair na Ala das Baianas da escola de Duartina, a Unidos da Vila, e desde lá não parou mais, só em 2021, por conta da pandemia da Covid-19.

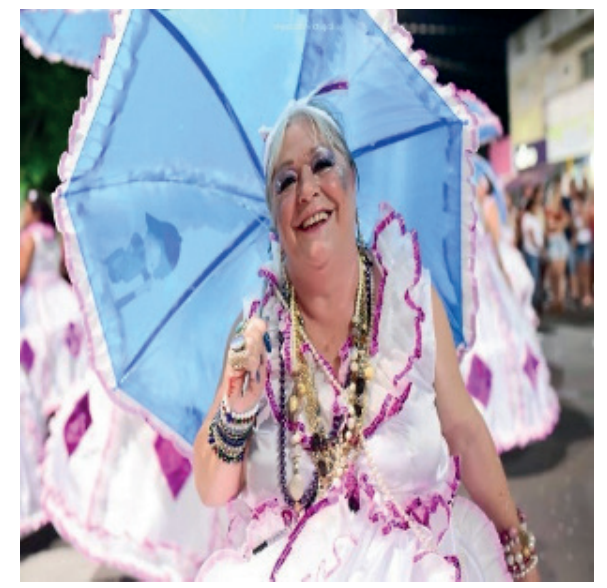

Imagem 12 - Dona Silvia Arena, 70 anos.

Fonte: arquivo das autoras.

Dona Silvia falou que ficou meio insegura em participar do desfile, pois estava com problemas na coluna. No entanto, insistiram no convite, que ela narra a seguir: 
Quer saber de uma coisa? Pode pôr meu nome que eu vou sim. Aí eu fiquei pensando, mas será que eu vou conseguir? Bom, se eu não conseguir, eu saio no meio, dou uma disfarçada e saio. Ah, minha filha! Quando eu pus a roupa, com aquele movimento, aquele monte de gente, aquela batucada, aquilo lá, parecia que eu era uma criança de sete anos, peguei fogo... [risos], não quis saber se tinha neto perto, se tinha filho, se tinha filha, se tinha gente que náo gosta, nora que não gosta, marido com cara feia, não quis nem saber, nem lembrei, parecia que não tinha marido e ele do meu lado. (Silvia Arena, 2017).

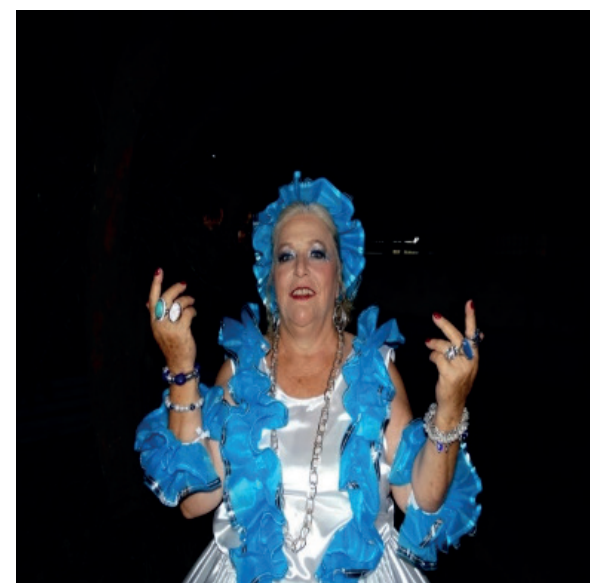

Imagem 13 - Dona Silvia de baiana, mostrando os acessórios (pulseiras, anéis, colares). Fonte: arquivo das autoras.

Dona Silvia ficou táo empolgada em participar que disse ter se esquecido das dores na coluna, pelo menos enquanto durava o carnaval. Nesse período, se preparava experimentando a roupa de baiana que uma costureira da cidade faz. Diz ficar muito empolgada ao se preparar para desfilar na avenida: coloca os adereços como brincos, colares, pulseiras e faz maquiagem. Sua empolgação era tamanha que outras senhoras da cidade quiseram também participar, além de sua cunhada que assistiu ao desfile em 2018 e decidiu participar em 2019, mesmo morando em Campinas.

Como foi relatado em trechos da entrevista anterior, Dona Silvia motivou sua cunhada Ourineusa, de 70 anos, a vir desfilar na Ala das Baianas de Duartina. Dona Ourineusa conta como foi isso: 


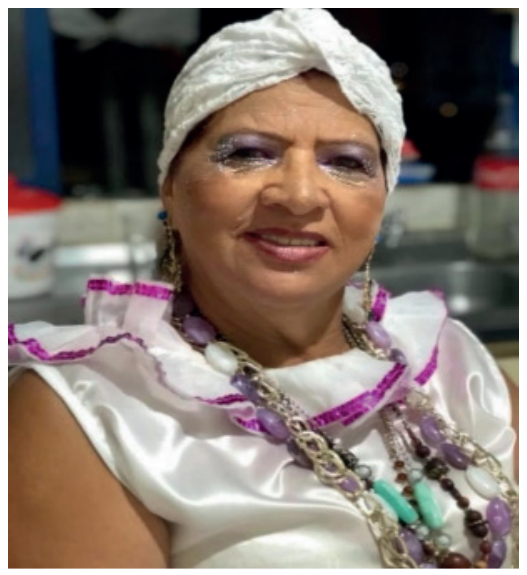

Imagem 14 - Dona Ourineusa Depieri, 70 anos.

Fonte: arquivos das autoras.

Eu fui passear lá no Carnaval, fui assistir o desfile, eu gostei e minha cunhada perguntou se eu queria desfilar lá, eu falei, pode marcar, aí a gente já foi falar com a costureira, aí a costureira pediu minhas medidas, ela já levou e ficou tudo certo, já marquei pro ano seguinte [2019]. Na hora em que assisti minha cunhada desfilar já me deu vontade de desfilar, porque eu sou farrista, a hora que eu a vi, eu disse o ano que vem eu venho também. É tudo uma brincadeira lá, sabe, a gente não compete, não tem qual foi melhor, nem qual escola foi pior, o gostoso é isso, ir para divertir, mas eles levam a sério, não é avacalhado, tudo em ordem, a gente não está concorrendo a nada, mas levam a sério, eu gostei, e a escola que desfilamos foi melhor, se fosse competir, teria sido a melhor, foi um capricho, capricharam nas fantasias. Cada bairro tem sua escola. (Ourineusa Depieri, 2018).

A senhora Ourineusa também ficou motivada ao se arrumar para o desfile. Lembra-se de ter ido comprar uma sandália, ter trocado acessórios com a cunhada, a filha de sua cunhada tê-las maquiado. Ela fala como se sentiu:

A sensação de tudo isso foi muito boa, acho que dá um ânimo na vida da gente, anima mesmo. No dia a dia, eu tenho essas lembranças, é algo que não esqueço mais. A gente fica contando os dias para chegar o próximo. (Ourineusa Depieri, 2018).

A senhora Ourineusa nos contou que, além de desfilar, fez muitas amizades no Carnaval de Duartina: com a costureira, com as senhoras da Ala das Baianas antes e durante o desfile. Ela, que morou em São Vicente (SP), se recorda que sempre gostou de Carnaval, levava seus filhos nas matinês no clube Portuário, em Santos (SP). Além disso, pulava carnaval à noite e levava os filhos para assistirem aos desfiles do carnaval de rua. 
Seu Alcenir Ladeia, sétimo e último entrevistado durante a pandemia, seguindo os protocolos do uso de máscaras e mantendo o distanciamento entre a pesquisadora e ele, narrou a seguinte história sobre sua participação no universo do samba, quando se mudou para Carapicuíba (SP):

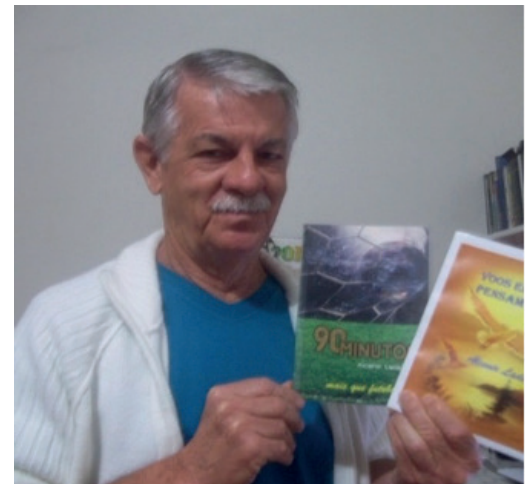

Imagem 15 - Seu Alcenir Ladeia, 75 anos, durante a entrevista.

Fonte: arquivo das autoras.

Como essa região de Carapicuíba é uma região com muito samba, um pessoal muito ligado ao samba, nós montamos uma escola de samba ali na Cohab [Companhia de Habitação] de Carapicuíba e o pessoal da Negritude na época tava montando o grupo. Esse grupo Negritude Junior participava da escola, entáo a escola teve um progresso rápido por causa disso. Aí eu fui presidente dessa escola de samba que nós fundamos, por cinco anos. Isso foi por volta de 78, entre 77 e 80 . Entáo, minha participação no samba realmente começou aí. Eu já gostava de samba, é lógico, mas penetrar numa escola de samba, mas conhecer... aí eu pra não ficar muito leigo no assunto, eu acabei fazendo alguns cursos na Mocidade Independente de Sáo Paulo, na escola de samba de Sáo Paulo e lá eu aprendi muita coisa: que numa escola de samba tem que saber que a maioria do público que participa da escola de samba, às vezes, não sabe... Eles não sabem, por exemplo, que a porta bandeira perde pontos se ela deixar a bandeira abaixar, que perde pontos se ela rodar muito rápido e não conseguirem ver a bandeira, o pavilhão da escola. Então, cada quesito de uma escola de samba, ele tem o seu segredo pra que ele náo perca ponto. (Alcenir Ladeia, 2020).

Seu Alcenir precisou se mudar para Campinas por conta do trabalho, e veio morar na Vila Bela, bairro da escola de samba Rosa de Prata. Apesar de ter deixado a Mocidade Independente de Carapicuíba, náo deixou de participar do samba, ele narra:

Eu mudei para a Vila Bela não por causa da Rosa de Prata, mas eu comecei a participar dos ensaios, porém o Carnaval de Campinas ficou parado muito tempo... 
e como eu tinha esse conhecimento que eu aprendi lá em Sáo Paulo, trouxe para a Rosa de Prata. Eu via a bateria tocando, chamava a atenção e era aqui perto de casa, aí eu ia assistir aos ensaios, já era aqui na Sede... Na época o diretor era o Marcos Arcada. Eu só participei da escola na fase final agora, no ano de 2013, 2014. Os três anos que eu fui da diretoria da escola foram 2013, 2014, 2015. Aí me convidaram para fazer parte da diretoria e eu acabei aceitando, porque sempre gostei do Carnaval e fiquei durante esses três anos como tesoureiro da escola, acho que por causa da idade, na época eu tinha quase 70 anos, porque hoje eu estou com 75. (Alcenir Ladeia, 2020).

\section{Considerações finais}

Após a exposição das narrativas dos idosos e suas participaçôes nas escolas de samba, podemos considerar que só teríamos acesso a essas experiências através da metodologia da História Oral. A possibilidade de poder trazer à tona experiências táo significativas na vida de idosos, pode contribuir para que estereótipos a respeito do envelhecimento sejam repensados (Santos; Silva, 2013).

Os idosos que participavam do carnaval, das escolas de samba, tinham momentos ativos, de trocas intergeracionais, de participaçôes em movimentos sociais e políticos e viviam momentos educativos.

Por meio dos relatos, pudemos perceber também que os idosos enfrentaram resistências ao participarem do folguedo, sejam as mulheres cujos maridos náo deixavam ou não viam com bons olhos sua participação no mundo do samba, seja pela crítica dos familiares, que possivelmente eram influenciados pelas ideologias de uma sociedade capitalista que pensa o velho como um ser sossegado, doente, cujo corpo náo pode ser exposto e que náo pode dançar. Uma sociedade que incentiva e valoriza os jovens, os corpos belos, principalmente no carnaval, espetáculo mostrado pelas mídias.

Superar a insegurança e a vergonha e descobrir um mundo empolgante, musical, artístico, de pura socialização e autonomia, mostra o quanto a participação na comunidade das escolas de samba evidencia uma contribuiçáo para o bem-estar dos idosos, com suas falas positivas e emocionadas ao relembrarem suas participaçóes no folguedo.

A interaçáo familiar possibilitada nas escolas de samba é uma forma de suporte aos idosos. Os filhos levavam os pais desfilar, depois estes envolviam os netos em prol do objetivo comum que era o amor pela escola, as trocas afetivas quando uma filha maquia a máe para sair de baiana, o amor que os idosos tinham pelas crianças da escola, seja criando alas para elas, como a das Baianinhas, ou como Seu Aluízio, que criou uma escola só de crianças, a Rosa do Futuro. 
A importância de pesquisar os idosos em carnavais ou escolas de samba se faz necessária para que suas memórias sejam deixadas como legados na forma de patrimônios imateriais e ajudem outros idosos a se integrarem aos carnavais ou sirvam como exemplo às novas geraçóes, contribuindo, assim, com as políticas públicas para os idosos, que não devem apenas focar-se na área médica, mas também na área dos relacionamentos sociais. O Estado deve assumir também seu papel de suporte e proteção aos idosos, incentivando e propiciando a eles atividades culturais e artísticas.

As artes transcendem o tempo, unem geraçóes, e as experiências de criação podem desenvolver nos sujeitos vitalidade e atributos psíquicos, como a ampliaçáo de consciência, observados em alguns depoimentos dos idosos que superaram dores, se sentiam alegres, animados ao participarem das escolas de samba e dos desfiles, seja fazendo fantasias, tirando alas, cuidando das crianças ou compondo sambas.

Desejamos que este artigo, além de rememorar momentos que trouxeram satisfação e qualidade de vida aos idosos, também seja um instrumento de reflexão sobre essa fase da vida e de sua importância. E, que assim que os idosos sejam vacinados no Brasil e que a pandemia da Covid-19 cesse, ou amenize, que o carnaval possa ser retomado e os idosos sejam valorizados e incluídos, principalmente no processo de desenvolvimento dessas festividades.

\section{Referências}

BOSI. Ecléa. Velhos amigos. São Paulo: Ateliê Editorial, 2019.

CÁNDIDA SMITH, Richard. Circuitos de subjetividade: História oral, arte e acervo. São Paulo: Letra e Voz, 2012.

DEZEMONE, Marcus. Narrativas do colonato: resistências cotidianas e porta-vozes no Sudeste cafeeiro - RJ. História Oral, v. 21, n. 2, p. 65-84, 2018.

LIMA, Angela Maria Machado de; SILVA, Henrique Salmazo da; GALHARDONI, Ricardo. Envelhecimento bem-sucedido: trajetórias de um constructo e novas fronteiras. Interface, v. 12, n. 27, 2008.

MEIHY, José Carlos Sebe Bom. Memória, História Oral e Diferenças. 1 vídeo (1h 36 min). Publicado pelo canal Instrumental Sesc Brasil, São Paulo, 1 nov. 2012. Disponível em: https:// www.youtube.com/watch?v=QvPyJ-OjsuM. Acesso em: 25 fev. 2021.

NOBILE, Lucas. Dona Ivone Lara: a primeira-dama do samba. Rio de Janeiro: Sonora Editora, 2015.

PERELMUTTER, Daisy. A História Oral como laboratório de sensibilizaçáo estética. In: SANTHIAGO, Ricardo (Org.). História Oral e arte: narração e criatividade. Sáo Paulo: Letra e Voz, 2016. p. 101-118.

ROVAI, Marta Gouveia de Oliveira. História Oral e história das mulheres: rompendo 
silenciamentos. São Paulo: Letra e Voz, 2017.

SANTHIAGO, Ricardo (Org.). História Oral e arte: narração e criatividade. São Paulo: Letra e Voz, 2016.

SIMSON, Olga Rodrigues de Moraes von. A construção de narrativas orais sugeridas e incentivadas pela visualidade. Campinas: Faculdade de Educação e Centro de Memória, Unicamp, [s. d].

TEIXEIRA, Ilka Nicéia D'Aquino Oliveira; NERI, Anita Liberalesso. Envelhecimento bemsucedido: uma meta no curso de vida. Psicologia USP, São Paulo, v. 19, n. 1, p. 81-94, 2008.

WORCMAN, Karen. Inovação e Criatividade: a história de Dona Isabel Mendes, das panelas de barro às bonecas de cerâmica. In: SANTHIAGO, Ricardo. História Oral e arte: narração e criatividade. São Paulo: Letra e Voz, 2016. p. 15-35.

\section{Fontes orais}

ARENA, Silvia [70 anos]. [set. 2017]. Entrevistadora: Matilde Corrêa. Campinas, SP, 7 set. 2017. AUGUSTO, Eliana [45 anos]. [ mar. 2019]. Entrevistadora: Matilde Corrêa. Campinas, SP, 23 mar. 2019.

DEPIERI, Ourineusa [70 anos]. [abr. 2018]. Entrevistadora: Matilde Corrêa. Campinas, SP, 26 abr. 2018].

JEREMIAS, Aluízio [80 anos]. [nov. 2019]. Entrevistadora: Matilde Corrêa. Campinas, SP, 29 nov. 2019.

LADEIA, Alcenir [75 anos]. [ago. 2020]. Entrevistadora: Matilde Corrêa. Campinas, SP, 23 ago. 2020.

SANTOS, Mercedes [69 anos]. [out. 2019]. Entrevistadora: Matilde Corrêa. Campinas, SP, 3 out. 2019.

SILVA, Irene da [86 anos]. [fev. 2019]. Entrevistadora: Matilde Corrêa. Campinas, SP, 18 fev. 2019.

Recebido em 27/02/2021.

Versão final reapresentada em 16/04/2021.

Aprovado em 28/04/2021.

Contribuiçóes dos autores: Simson: revisão e sugestôes de referências bibliográficas.

Certificado de Apresentaçáo de Apreciação Ética (CAAE): 22425319.0.0000.5404.

Fonte de financiamento: nada a declarar.

Conflitos de interesse: a autora possui relação de parentesco com uma das entrevistadas da pesquisa, a Sra. Silvia Arena é sua tia paterna. 